\title{
HOW A BETAWINESE FAMILY IMPLEMENT POLITENESS IN THEIR DAILY CONVERSATION
}

\author{
Triana Salihah ${ }^{1}$; Menik Winiharti² \\ 1,2English Department, Faculty of Humanities, Bina Nusantara University \\ Jl. Kemanggisan Ilir III No. 45, Palmerah, Jakarta Barat 11480, Indonesia \\ 'menikwiniharti@yahoo.com
}

Received: $18^{\text {th }}$ April 2016/ Revised: $4^{\text {th }}$ May 2017/ Accepted: $7^{\text {th }}$ August 2017

How to Cite: Salihah, T. \& Miniharti, M. (2017). How a Betawinese Family Implement Politeness in Their Daily Conversation. Lingua Cultura, 11(2), 91-96. http://dx.doi.org/10.21512/lc.v11i2.924

\begin{abstract}
This research was aimed at finding the politeness strategies used by the members of a Betawinese family in their daily conversation. It was also conducted to describe the extent to which the family members apply politeness in everyday conversation. The data were collected from a Betawinese family that was consisting of six members, who still speak the Betawi language in their daily lives. The observation toward the family was conducted and recorded whenever they spoke to each other. The data were then analyzed based on each speaker and addressee in applying the politeness strategy. The result shows that there are four politeness strategies used: Bald on Record, Off Record, Positive Politeness, and Negative Politeness. The speakers who have a higher status in the family potentially threaten the 'face' of the hearers with a lower status. This research also finds that the selection of politeness strategies is determined by two factors; (1) the status of the family members within the family itself, and (2) the intensity of inter-speaker meeting. Moreover, it is proven that a Betawinese family applies certain politeness strategies in their daily conversation.
\end{abstract}

Keywords: politeness strategy, family member, family status, conversation

\section{INTRODUCTION}

Every language has several entities that may not be owned by other languages. That is why it is special and unique. The uniqueness of a certain language is strongly influenced by the culture of the native speakers, i.e., people who speak the language. Moreover, the manner in a conversation that is shown by speakers is an important thing to be considered. In this case, people who are involved in an interaction, indirectly create some norms and principles that arise in the community as their politeness standards (Yule, 1996). Thus, there is no doubt that language expresses the speaker's identity.

Sukma (2014) has suggested that the government of Indonesia has supported the use and function of local languages, along with the Indonesian language. Their existence is guaranteed by the Constitution of the Republic of Indonesia. Cohn et al. (2014) have also stated that hundreds of distinct languages have been used as native languages throughout the archipelago and that multilingualism has been the norm. A local language in Indonesia that still exists today is Betawinese, which is almost as old as the name of the area where the language was developed, i.e., Jakarta. Grijns (1991) has stated that besides local Indonesian languages, such as Javanese and Sundanese, Betawi Malay is one of the most important everyday languages that is spoken in Jakarta. The language is a language of an intergroup society that is concerned with diglossia; the use of Malay-Jakarta which is limited according to the situation.

The name of Betawi itself is derived from Batavia, a Dutch colonial city during Indonesia's colonial era. In the present days, the name involves the people who originally inhabit Jakarta area, the culture, tradition, and certainly the language.

Betawi language, as Sugiharto (2008) has stated, is one of the most widely-spoken among an estimated number of 746 indigenous languages in Indonesia. It is listed as one of Indonesia's active local languages, spoken by around 2,7 million people in the greater area of Jakarta. In addition, those who have lived in Jakarta for quite a long time are familiar with the language. Thus, the use of this language is no longer limited to those who are natively Betawinese.

In terms of linguistics, Muhadjir (2000) has pointed out that the most prominent difference between Betawi language with other Malay language is the number of vowel $\grave{e}$, such as apè, adè, and ayè. The sound è (pepet) which is used with consonants in the final syllables is also frequently used, such as in dateng, bekel, and bareng. When Indonesian language is used, there is a very distinctive characteristic, i.e. replacing the prefix me- with nasal $n g$ - such as ngambil 
for mengambil (take), and ngambek for marah (mad). Sahara (2014) also has pointed out that Betawinese people show a characteristic by changing the phonemes /a/ into /e/, $/ \mathrm{u} /$ into /o/, /o/ into /u/; as in apa into ape, Rabu into rebo, and mobil into mubil.

The emphasis of suffix /e/ in Betawinese causes the language to be heard more loudly or sharply. People (usually from other ethnics) who are either unfamiliar with Betawi ethnic and language or rarely hear conversations in Betawinese, usually assume that the Betawi language is rude. In fact, it is only due to a simplistic view on their pronouns which are identical with elu (you) and gue (me) that may make the language seem rude. Within this context, Cohn \& Ravindranath (2014) has suggested that although Indonesians often use the terms kasar (rude) and sopan (polite) to refer to informal and formal diction respectively, it is not likely to associate informally with rude and formal with polite.

Filia (2012) has found that there are three phonological variants of Indonesian phatic particles used in Betawi dialect: yak, ye, and si. The rising intonation tends to be used at the end of the utterance. Moreover, turn-taking is identified with high intonation. However, the tendency to use high intonation cannot be interpreted as a lower level of politeness. She adds that according to the informants, there is a misperception that the high tone shows annoyance or anger. Therefore, in terms of politeness, the rising intonation that is usually found in the Betawi language does not always mean that the speaker is impolite.

Fahrizal (2001) has found that in the scope of a family, the Betawi language is generally still very communicative. He reveals that in a Betawinese family, the use of Betawi language among adults and children is still considerably frequent. This is mainly due to the participants having a family relationship. He also discovers that the communication between siblings in a Betawinese family is basically equal, but those who are older may feel entitled to certain rights over their younger siblings. They rule the younger and have the rights to speak more loudly, even to the point of sounding rude. Unfortunately, not all younger siblings have the courage to respond toward the arrogance of their older siblings. He concludes that in terms of the norm of interpretation, the use of Betawi language within a family in a formal conversation is considered normal and does not show rudeness (Fahrizal, 2001).

This research explores the language used in a Betawinese family. It discusses the way the family communicates to each other, in terms of the politeness strategies that they use in daily conversations. The aims are to find these politeness strategies and to describe the extent to which the family members apply politeness in everyday conversation. Therefore, this research functions to provide valuable inputs on whether a Betawinese, who are often judged as sounding rude, applies certain politeness strategies in their everyday conversation. It is also to provide additional knowledge that people are speaking a local language also apply politeness strategies.

According to Yule (1996), politeness is showing awareness of another person's face; it is related to social distance or closeness. Brown \& Levinson in Watts (2003) has argued that each member of a society is endowed with the face, which is the public self-image that every member wants to claim for himself. Thus, any human interaction will always be potentially threatening to the hearer's face. So, it is in the best interest of each speaker to protect the other's face by softening or avoiding the impact of face- threatening acts (FTA) - acts that infringe on the hearer's need to maintain his/her self-esteem, and to be respected. Politeness strategies are developed for the main purpose of dealing with these FTAs.

There are four politeness strategies as proposed by Brown \& Levinson in Watts (2003). They are Bald on Record, Off Record, Positive Politeness, and Negative Politeness. Bald on Record strategy provides no effort by speakers to reduce the impact of the FTAs. It will rather shock the hearers and embarrass them, or make them feel a bit uncomfortable, for example: (a) Give me a pen, and (b) Lend me your pen. Another choice of words to reduce the severity of FTA done by the speaker is by mitigating devices such as 'would you?' and 'please'. The mitigating devices will be appropriate in the words of direct command or imperative because they are used by people who have a high solidarity (Yule, 1996).

In Off Record strategy, the speakers express their desire indirectly. They might be using a statement as a hint for the hearers, for example (a) Uh, I forgot my pen, and (b) Hmm, I wonder where I put my pen. The Positive Politeness strategy is used to minimize the distance between the speakers and hearers by expressing friendliness and solid interest in the hearer's need to be respected (minimizing the FTA). The examples for this strategy are (a) How about letting me use your pen?; and (b) Hi buddy, I'd appreciate it if you'd let me use your pen. The next strategy is Negative Politeness. The main focus for using this strategy is to assume that you may be imposing on the hearer, and intruding on his space. For example: (a) I'm sorry to bother you, but can I ask you for a pen or something?; and (b) I know you're busy, but might I ask you if-em-if you happen to have an extra pen that I could, you know-eh-maybe borrow?

Holmes (2008) has pointed out that social relationships among people in the society are based on some rules, values, etiquette, etc. In communication, for instance, people are ordered by rules (of speaking), they are guided by values (of how to behave in a good manner) that can be conducted through etiquette (of using a language). This means that one has to apply regulation in using the language. Moreover, in using a language, someone has to consider to whom he/she speaks. By doing that, he/she will determine what language or its varieties he/she wants to use to speak. According to Holmes (2008), the consideration is not only based on to whom he/she speaks, but also when or where he/she speaks. In other words, the language speaker will consider the setting of time and place. Furthermore, the language used is determined by social dimensions, which are social distance scale (how well the interlocutors know each other), a status scale (high-low status in social life; superior-subordinate status), a formality scale (formalinformal; high-low formality), and the functional scale (the purpose or topic of an interaction) (Holmes, 2008).

\section{METHODS}

The data of the research were a Betawinese family from Pondok Aren, Tangerang, which is an area in the west of Jakarta. The family still uses Betawi language in their daily conversation. There are six family members to be observed; father (52 years old), mother (45 years old), three daughters $(26,20$, and 15 years old each), and a son (17 years old).

For this research, the data were collected from April 3, 2014, until April 9, 2014, by observing and monitoring the family members when they talk to each other. The 
conversations on the special event (Indonesian General Election) involving their big family is also observed. The observation focuses on politeness strategies used by each member of the family in their daily conversation. The conversation observed includes the language that is used among the speakers, as parents to children, children to parents, wife to husband, husband to wife as well as the conversation between the children themselves. The observation or monitoring is conducted for one week inside the house of the family.

After the data are collected, the utterances are selected based on the politeness strategies that are used by the family members. The data are then analyzed based on the conversations that happened between parents and children, wife and husband, as well as the conversation between the children. The theory used for the analysis is mainly of Politeness Strategies that is proposed by Brown \& Levinson in Watts (2003). The use of each type of politeness strategies is analyzed based on the interlocutors (speaker and addressee), their status within the family, the topic, and the situation. For each member of the family, the reason for using certain politeness strategies is also analyzed.

\section{RESULTS AND DISCUSSIONS}

The analysis is done by sorting the type of politeness strategies that are found in the conversations among the family members. There are Bald on Record, Off Record, Negative Politeness, and Positive Politeness. To make the analysis easier, the respondents are coded as:

$\mathrm{F}$ is Father,

$\mathrm{M}$ is Mother,

D1 is the oldest Daughter,

D2 is the second Daughter,

$\mathrm{S} 3$ is the third Son, and

D4 is the youngest Daughter.

There are 53 dialogues that were recorded. However, due to the space limits, only two examples of each type of politeness strategies are discussed. Two dialogues above are the examples of Bald on Record strategy.

In the dialogue, the conversation between the second daughter (D2) and the youngest daughter (D4) happens in their bedroom. There are also friends of D2 and a friend of D4. D2 requests D4 to get her a glass of water. However, because D4 is so busy with her gadget, she was not aware that D2 asks for help.

\section{D2 : Nad, ambilin minum dah?"}

"Nad, bring me the drink?"

D4 : “......." (no response, she is busy with her gadget)

D2 : Lu denger gak sih gue ngomong?" "Do you hear me speak, don't you?"

D4 : "Ntar dulu kek.." (still on her gadget) "Can you wait?"

D2: "Lama lu...buruan aus gue." (with a higher tone)

"Why it takes so long? I'm thirsty."

The way D2 asks for help is identified as Bald on Record strategy since it provides no effort by the speaker to reduce the impact of the FTAs. D2 is showing FTA to D4 because it happens in front of their friends. Therefore, D4 as the younger sister might feel uncomfortable and ashamed at that time. In this context, it is shown that D2 threatened the face of D4. In other words, D2 does not pay attention to the positive face of $\mathrm{D} 4$. The most possible reason as to why D2 does that is because D4 is the youngest sister.

The next dialogue occurs in a family gathering. The father (F) participates in a successful team of a political party, so he informs all relatives that the Indonesian legislative election would be held soon.

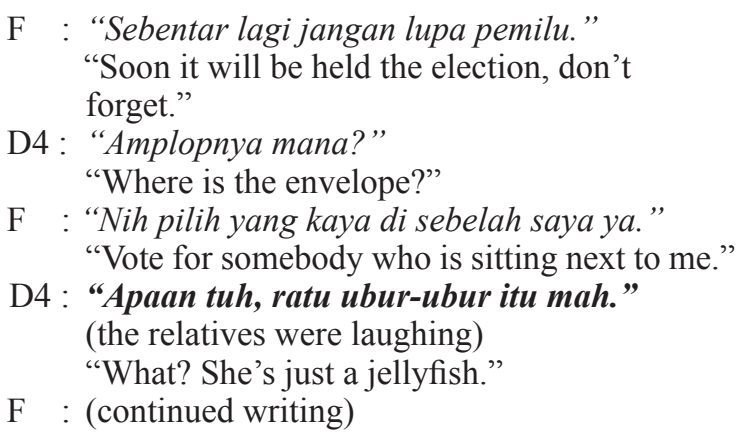

In this situation, $\mathrm{F}$ is giving information to his relatives regarding the legislative election. He asks his relatives to vote for somebody sitting next to him. D4 directly responds to his request by telling a joke, saying apaan tuh, ratu ubur-ubur itu mah. She uses ratu ubur-ubur that refers to someone who is sitting next to $\mathrm{F}$, but that someone is not actually D4's target. She says it is as a respond to her father that shows she does not really like her father's friend. This joke is told baldly in front of the relative that gives impact to $\mathrm{F}$ which then feels embarrassed and annoyed. That is mostly due to D4, who is still a teenager that makes fun of F's friend while $\mathrm{F}$ is talking seriously with the relatives. D4 assumes that it is fine to tell a joke, even though it is made to his father and in a serious situation.

The Off Record strategy can be seen in dialogue between the oldest daughter (D1) and the second daughter (D2). They are having a conversation at their house in the evening. At that time, D1 is watching television while D2 who is sitting next to D1, busy with her gadget.

\section{D1: "Enak kali nih makan soto ceker yang di deket rumah Fisha." \\ "It is good idea if we are eating soto ceker that is near from Fisha's house." \\ D2 : (no response) \\ D1 : "Enak kali nih makan soto ceker yang di rumah Fisha."}

"It is good idea if we are eating soto ceker that is near from Fisha's house."

D2 : (no response)

To express her desire, D1 has said "enak nih kalo makan soto ceker yang di deket rumah Fisha" as a hint that she wanted to eat Soto. However, D2 does not give any responses. She is still busy with her gadget. Moreover, when D1 feels that D2 does not listen to or pay attention to her, she repeats the utterance for D2 to listen and pay attention to what she is saying. In this situation, D1 uses the off record strategy by expressing her desire indirectly. It is indicated when D1 says the utterance as a hint to D2 as she does not command D2 directly. However, the strategy does not work at that time because D2 is not aware that D1 has commanded her. The choice of strategy that is used by D1 is determined by the status of D1 who is older than D2. She wants to be served by her younger sister. Next dialogue happens in the 
front yard of the family's house, at about 2 o'clock in the afternoon, the father $(\mathrm{F})$ is talking with his daughter and her friend while the mother (M) is inside the house.

\section{M: “Itu mobil cantik banget biar kaga mandi yak, bukan maen..." \\ "That car is really beautiful even though it has not been washed yet, amazing.." \\ F: "Bawa ke Bintaro aja noh suruh Fadil aja." "Asked Fadil to bring it to Bintaro."}

In this situation, $\mathrm{M}$ comes out and says "Itu mobil cantik bener biar kaga mandi yak bukan maen”. What M talked about is the opposite of the real fact, because the car is actually very dirty that it must be cleaned. It is actually a hint that the car is not clean. Fortunately, F immediately understands what $\mathrm{M}$ intends to say. Then, F replied "Bawa ke Bintaro aja noh suruh si Fadil”, which means that Fadil, the son, should drive the car to a car wash in Bintaro. In this case, M uses the off record strategy which is successfully interpreted by F. She prefers to use the strategy to save F's positive face because his daughter and her friend are there.

The next dialogue is the example of Negative Politeness strategy. The short conversation happens between $\mathrm{F}$ and $\mathrm{M}$ while having dinner together.

M : “Pa, mama kan besok mau pergi sama ibuibu, kayaknya mah si Lia juga mao ngikut. Besok Mama bagi duit ya Pa?"

"(Tomorrow, I will go somewhere with my friends and Lia wants to join. Please give me money for tomorrow, okay?"

F : "Hmm..."

M : “Ya'elah si Papa mah hmm hmm doangan..." "And that's my Father, only hmm hmm"

According to the utterance spoken by $M$ to $F$, it is identified as Negative Politeness strategy. In this situation, before $\mathrm{M}$ asks $\mathrm{F}$ for some money, she first told him the reason, which is because she wants to go out with her friends. She also says it politely. She respects him not only because he is her husband but also because he is older than her.

\section{Dialogue 6}

The next dialogue happens in the evening, when $\mathrm{M}$ is watching television in her bedroom, and D4 comes and approaches $\mathrm{M}$.

D4 : “Ma, minggu depan kan Iya bayaran les. Tapi bisa dicicil dulu Ma mulai besok. Besok Iya bagi duitnya ya Ma?"

"Mother, I must pay my course fee. But the payment can be purchased on installment from tomorrow. Can you give me the money tomorrow?"

M : "Berapa emang? Ngambil duit dulu di ATM besok dah."

How much is it? I will take the money tomorrow in ATM.

D4 : "Yah lupa berapa yak? Entar dah Iya cari dulu kartu bayarannya."

I forget. Let me see the payment card first.

In this situation, D4 tells M that the following week is the time to pay the course fee. She asks her mother to pay the fee. It is shown that D4 uses Negative Politeness to her mother because she explains the situation first before she tells her the final intention. This strategy is used in the fear that the speaker may be imposing on the hearer, and intruding her space. In addition, the use of this strategy is determined by the distance rating, in which $\mathrm{M}$ is much older than D4. M is also someone whom D4 must respect.

The Positive Politeness can be seen in this nest dialogue. It happened on the Election Day, April 2014. The election was held to appoint members of the legislative, in front of the grandmother's house. All members of the big family were ready to participate. $M$ has cast her vote, and it was D2's turn to cast her vote.

\section{M : "Neng, nih yang penting mah no. 2 Golkar yak, yang laen mah kaga penting.” "Girl, the most important thing is number 2, Golkar, others are not that important." \\ D2 : "Iye..",}

There are many relatives who have gathered in front of the house to participate in the election. The utterance in the above dialogue is spoken by $\mathrm{M}$ that asks D2 to choose their relative in the legislative election. $\mathrm{M}$ has always reminded her daughters about that. A minute before D2's turn to cast her vote, $\mathrm{M}$ still reminds her about the legislative candidate that should be elected. The way $M$ reminds her daughter is identified as Positive Politeness because $\mathrm{M}$ tries to minimize D2's FTA. However, D2 seems annoyed because M talks about the same thing for many times. D2 answers M with a short reply to express that she already understood what her mother wants. In addition, the strategy choice that is used by $\mathrm{M}$ is determined by the status of $\mathrm{M}$ as the mother (the older person).

The next dialogue happens on one evening when a friend of one of the daughters is coming to the family's house. S3 and his sister's friend have a conversation in the living room. They talk about college for quite some time. All of a sudden, $\mathrm{M}$ comes out of her room and heads to the kitchen.

\section{M : "Dil... Dil... ada cewek mah beliin bakso kek, ini mah tiduran bae." \\ "Dil...Dil... there is a female guest, please buy bakso for her, why are you just sleeping? \\ S3 : "Gak ada duit." \\ "I don't have any money".}

In this situation, $\mathrm{M}$ asks her son to buy bakso for the female guest, his sister's friend. The utterance is spoken by $\mathrm{M}$ actually contains a suggestion as well as a joke. It is identified as Positive Politeness strategy since she tries to give a suggestion to $\mathrm{S} 3$ to buy bakso for the female guest. This strategy is also determined by the status of $M$ as the mother (older person). Thus, she might feel that asking him to do so is appropriate. However, the response of S3 indicates that he does not intend to buy bakso for the guest.

Table 1 shows the distribution of the use of politeness strategy. This research has recorded 53 dialogues that are spoken by six family members. The table shows that the family indeed uses politeness strategies. Out of all the recorded dialogues, the most frequently used strategy is Bald on Record, which results in 19 times. The second one is Off Record strategy, with 15 times. Lastly, Negative Politeness is used for 10 times, and Positive Politeness 9 times. 
Table 1 The Distribution of the Use of Politeness Strategies

\begin{tabular}{|c|c|c|c|c|}
\hline Strategy & Speaker & Addressee & Reason & Frequency \\
\hline On record & D2 & D4 & Older person & 5 \\
\hline On record & D4 & M & Younger person & 2 \\
\hline On record & D4 & $\mathrm{F}$ & Younger person & 1 \\
\hline On record & M & D4 & Parent to daughter & 2 \\
\hline On record & S3 & D2 & Younger person & 2 \\
\hline On record & $\mathrm{F}$ & D2 & Father to daughter & 3 \\
\hline On record & D2 & M & Younger person & 1 \\
\hline On record & $\mathrm{F}$ & M & Older person & 1 \\
\hline On record & D4 & $\mathrm{S} 3$ & Younger person & 1 \\
\hline \multirow[t]{2}{*}{ On record } & M & $\mathrm{S} 3$ & Mother to son & 1 \\
\hline & & & Total & 19 \\
\hline Off record & D1 & D2 & Older person & 2 \\
\hline Off record & D4 & D1 & Younger person & 1 \\
\hline Off record & M & D4 & Mother to daughter & 1 \\
\hline Off record & D2 & $\mathrm{F}$ & Younger person & 2 \\
\hline Off record & M & $\mathrm{F}$ & Younger person & 2 \\
\hline Off record & D2 & $\mathrm{S} 3$ & Older person & 1 \\
\hline Off record & D4 & M & Younger person & 2 \\
\hline Off record & $\mathrm{F}$ & M & Older person & 1 \\
\hline Off record & D1 & M & Younger person & 1 \\
\hline Off record & S3 & D2 & Younger person & 1 \\
\hline \multirow[t]{2}{*}{ Off record } & $\mathrm{F}$ & D2 & Father to daughter & 1 \\
\hline & & & Total & 15 \\
\hline Negative politeness & $\mathrm{M}$ & $\mathrm{F}$ & Younger person & 1 \\
\hline Negative politeness & D4 & M & Younger person & 1 \\
\hline Negative politeness & D2 & D4 & Older person & 1 \\
\hline Negative politeness & D1 & D2 & Older person & 2 \\
\hline Negative politeness & D4 & D1 & Younger person & 1 \\
\hline Negative politeness & D2 & D1 & Younger person & 1 \\
\hline Negative politeness & D4 & D2 & Younger person & 1 \\
\hline \multirow[t]{2}{*}{ Negative politeness } & D4 & $\mathrm{S} 3$ & Younger person & 2 \\
\hline & & & Total & 10 \\
\hline Positive politeness & M & D2 & Mother to daughter & 4 \\
\hline Positive politeness & M & $\mathrm{S} 3$ & Mother to son & 1 \\
\hline Positive politeness & D4 & D2 & Younger person & 1 \\
\hline Positive politeness & D4 & M & Younger person & 1 \\
\hline Positive politeness & D1 & $\mathrm{S} 3$ & Older person & 1 \\
\hline \multirow[t]{2}{*}{ Positive politeness } & $\mathrm{F}$ & M & Older person & 1 \\
\hline & & & Total & 9 \\
\hline
\end{tabular}

\section{CONCLUSIONS}

It is found that the family uses four types of politeness strategies: Bald on Record, Off Record, Negative Politeness and Positive Politeness. Each use of the politeness strategies is determined by the status of the speaker toward his/her addressee. Different status in the family becomes the basis for the selection of the appropriate language in communicating with each other. Bald on Record strategy is most frequently used by the second daughter (D2), which is five times out of 19 times. It can be said that Bald on Record is the most direct strategy. In this context, D2 mostly uses this type when she has a conversation with her little sister, D4. The status of D2 - the older sister- affects her choice of language. Furthermore, the Off Record strategy is used to express speakers' desires implicitly. They prefer to use hints or to inform something which is implied to the hearers, and the hearers are expected to get the indirectly conveyed message. This strategy is used for 15 times. The speakers who use this strategy are D1, D2, D4, and M. Three of them 
(D1, D2, and D4) have the status of the younger ones to their addresses when they apply the strategy. This status really affects them to use the strategy in their daily conversations.

The third most frequently used strategy is Negative Politeness. It is also an indirect strategy even though it is expressed explicitly. This strategy is used by D1 and D4 for two times out of 10 times. Since D1 has moved to her new house, she does not meet the other family members often. She also rarely has a conversation with her siblings, including her parents. Thus, it can be said that this condition creates a distance with D2 and other family members. The age difference between D1 and her little sister, D4 as well as her brother also influences them in using this strategy. In addition, the less frequent meetings between D1 and other family members also affect the use of their politeness strategy. This condition indicates that one's status in the family, as well as the distance factor, affect the choice of politeness strategy to use.

The least frequently used strategy is Positive Politeness. The focus of this strategy is to minimize the distance among the interlocutors. The speaker uses this type to express his or her closeness. In this case, the mother (M) uses this strategy most frequently, which is four times out of nine times. It is often done to D2 because $\mathrm{M}$ is very close to her second daughter. $\mathrm{M}$ uses this strategy more to command and forbid D2 when the daughter tries to do something. Moreover, the status of $\mathrm{M}$ as the mother also affects her to do this strategy more often.

In conclusion, politeness has become a phenomenon in every human communication, which includes communication within the scope of a family. It is because it can be a tool to avoid conflict among the interlocutors. This study points out that in a Betawinese family who speak Betawi language, politeness strategies are applied even though in some cases they may sound rude for using a high tone. Moreover, when someone speaks to other members of the family, the way he/she talks would be different from the way he/she communicates with his/her peers. It can be said that this happens because there is a difference of status in the family.

\section{REFERENCES}

Cohn, A. C., \& Ravindranath, M. (2014). Local Languages in Indonesia: Language Maintenance or Language Shift? Masyarakat Linguistik Indonesia, 32(2), 131148.

Cohn, A. C., Bowden, F. J., Mckinnon, T. A., Ravindranath, M., Simanjuntak, R. P., Taylor, B., \& Yanti. (2014). Assessing the Impact of Indonesian on the Maintenance of Local Languages. Kongres Internasional Masyarakat Linguistik Indonesia 2014, pp. 13-17.

Fahrizal. (2001). Penggunaan Bahasa dan Identitas Etnik: Studi Penggunaan Bahasa Betawi dalam Tindak Komunikasi Orang Betawi di Condet (Master's Thesis). Depok: Universitas Indonesia.

Filia. (2012). Alih Bicara dalam Percakapan Bahasa Indonesia Dialek Betawi. Prosiding the 4th International Conference on Indonesian Studies: “Unity, Diversity and Future”, pp. 278-288. Depok: Fakultas Ilmu Pengetahuan Budaya, Universitas Indonesia.
Grijns, C. D. (1991). Kajian Bahasa Melayu-Betawi. Jakarta: PT. Pustaka Utama Grafiti.

Holmes, J. (2008). An Introduction to Sociolinguistics. Edinburgh: Pearson Education Limited.

Muhadjir. (2000). Bahasa Betawi: Sejarah dan Perkembangannya. Jakarta: Yayasan Obor Indonesia.

Sahara, S. (2014). Interferensi Bahasa Betawi dalam Cerpen Mahasiswa Jurusan PBSI FITK UIN Syarif Hidayatullah Jakarta. Dialektika, 1(1), 109-130.

Sugiharto, S. (2008, 21 June). The perseverance of Betawi language in Jakarta. Retrieved from http:// www.thejakartapost.com/news/2008/06/21/theperseverance-betawi-language-jakarta.html

Sukma, R. (2014). Pemanfaatan Lenong Betawi sebagai Wahana Pelestari Bahasa Ibu (Betawi): Kasus Berkembangnya Bahasa Alay dalam Ranah Bahasa Remaja di Jakarta. Kongres Internasional Masyarakat Linguistik Indonesia 2014, pp. 467-471.

Watts, R. J. (2003). Politeness. Cambridge: Cambridge University Press.

Yule, G. (1996). Pragmatics. New York: Oxford University Press. 